\title{
Fishermen Adherence on Source Utilization in Southeast Aru Conservation Area
}

\author{
Fernando D.W. Dangeubun \\ Department of Aquatic Resources Management Faculty of Fisheries and Marine Sciences \\ Pattimura University Jl. Ir. M. Putuhena, Campus Poka Ambon \\ E-mail: Fernando_dange@yahoo.com
}

Doi:10.5296/ijhrs.v3i4.4719

URL: http://dx.doi.org/10.5296/ijhrs.v3i4.4719

\begin{abstract}
Southeast Aru Conservation Area is stipulated in the decree of Ministry of Forestry of the Republic of Indonesia No. 27/Kpts-II/1991, as Marine Sanctuary which is fully managed by Department of Forestry Affairs, henceforth it is returned to the Ministry of Marine and Fisheries in 2009 through the decree of the Ministry of Marine and Fisheries No. 63/Men/2009 under the status of Water Nature Reserve (IN: Suaka Alam Perairan/SAP). Purpose of the establishment is to preserve endemic source which should be retained altogether with its ecosystem diversity. Decreasing of this existence along with the utilization rate by society which is predicted as simultaneity of society's social, economic and culture variables becomes the aim of this study to understand some factors. These factors affect the decision of society in adhering or violating formal regulation about conservation to formulate continuous management plan. Data collection method was performed by structured interview supported with list of questions, while analysis was performed by using basic model of adherence and renewable adherence model. Based on the analysis result, it is concluded that some factors affecting society's decision in adhering or violating formal regulation about conservation include economic profit frequency if the society catches fishes in conservation region, law enforcement capacity by Jagawana (EN: Rangers), productive age level and experienced men to access the sources as well as the background of society.
\end{abstract}

Keywords: Adherence, Source Utilization, Conservation Area.

\section{Introduction}

Southeast Aru Conservation Area is one of the conservation areas which is stipulated as conservation area by the central government based on the decree of Ministry of Forestry of the Republic of Indonesia No. 27/Kpts-II/1991 under the status of Southeast Aru Marine Sanctuary (MS). Southeast Aru MS area was appointed as conservation area based on the survey result of biophysical and socio-economical that this area must be retained because it had potentials endemic resources which should be protected, including turtle, dugong, and crocodile, supported with its ecosystem diversity and complexity.

Besides the consideration of biophysical parameter as explained above, another reckoned 
consideration in appointing this region as conservation area are that:

a. This is an area with 7 islands, from which 3 islands of them are the outermost border islands between the government of Indonesia and Australia. The three intended islands are Enu, Coral, and Kultubai Selatan Island.

b. A region with its 7 islands consists of very small and uninhabited islands.

c. Among these seven islands, the two of them called as Enu and Coral Island are historical islands for all people in Aru because they were the place of origin away back (historical stories of Aru people), while the other 5 islands are historical islands for several surrounding villages, that are village of Longgar, Apara and Bemun.

d. Southeast Aru Conservation Areas are opposite directly to fishing ground in Arafura Sea. In the time of appointment as Marine Sanctuary (MS), southeast Aru conservation area is fully managed by Department of Forestry Affairs under province based management called as Natural Resources Conservation Service/NRCS (IN: Badan Konservasi Sumber Daya Alam/BKSDA). Furthermore, it is returned to Ministry of Marine and Fisheries in 2009 through the decree of the Ministry of Marine and Fisheries No 63/Men/2009 under status changing of Southeast Aru Water Nature Reserve (WNR), with geographic coordinates at Table 1 and Figure 1.

Table 1 Frontier coordinate (degrees-minutes-seconds) of Southeast Aru Conservation Area

\begin{tabular}{ccccccc}
\hline & \multicolumn{3}{c}{ Latitude } & Longitude \\
\cline { 2 - 7 } Point & $\begin{array}{c}\text { Degrees } \\
\left({ }^{0}\right)\end{array}$ & $\begin{array}{c}\text { Minutes } \\
\left({ }^{\circ}\right)\end{array}$ & $\begin{array}{c}\text { Seconds } \\
(\text { “c }\end{array}$ & $\begin{array}{c}\text { Degrees } \\
\left({ }^{0}\right)\end{array}$ & $\begin{array}{c}\text { Minutes } \\
\left({ }^{\circ}\right)\end{array}$ & $\begin{array}{c}\text { Seconds } \\
(\text { “") }\end{array}$ \\
\hline 1 & 6 & 49 & 4 & 134 & 41 & 24 \\
2 & 6 & 51 & 32 & 134 & 46 & 9 \\
3 & 6 & 58 & 13 & 134 & 49 & 18 \\
4 & 7 & 2 & 18 & 134 & 44 & 14 \\
5 & 7 & 8 & 15 & 134 & 29 & 15 \\
6 & 7 & 7 & 2 & 134 & 23 & 31 \\
7 & 6 & 56 & 5 & 134 & 27 & 13 \\
8 & 6 & 54 & 5 & 134 & 29 & 26 \\
\hline
\end{tabular}

Southeast Aru conservation area with 114,000 Ha width is dominated by open water zones by $85.06 \%$ while the lowest position is at mangrove forest ecosystem zones with percentage by $1.69 \%$ (Table 2). The existing ecosystem condition in Southeast Aru conservation area gives a strong contribution to the habitat, hunting and breeding sites for various resources inside of it. 
Table 2 Zone area in Southeast Aru Conservation Area

\begin{tabular}{lccccccccc}
\hline Zone Area & $\mathbf{1}$ & $\mathbf{2}$ & $\mathbf{3}$ & $\mathbf{4}$ & $\mathbf{5}$ & $\mathbf{6}$ & $\mathbf{7}$ & $\begin{array}{c}\text { Total } \\
(\mathbf{K m 2})\end{array}$ & \% \\
\hline Island Area & 14.38 & 3.30 & 0.82 & 6.68 & 1.79 & 16.18 & 5.69 & 48.85 & 4.28 \\
Mangrove & 10.01 & 2.10 & 0.06 & 2.84 & 1.04 & 1.20 & 1.98 & 19.24 & 1.69 \\
Seagrass & 0.86 & 2.80 & 1.31 & 0.74 & 9.72 & 50.02 & 7.89 & 73.34 & 6.43 \\
Coral & 3.41 & 4.94 & 2.00 & 1.99 & 5.00 & 6.53 & 5.05 & 28.92 & 2.54 \\
Open Waters & & & & & & & & 169.655 & 85.06 \\
\hline Total & & & & & & & & 114,000 & 100 \\
\hline
\end{tabular}

Description:

$1=$ Enu Island

$3=$ South Kultubai $5=$ Mar Island $\quad 7=$ Marjinjin Island

2.= Karang Island

$\begin{array}{ll}\text { Island } & 6=\text { Jeudin } \\ 4=\text { Jeh Island } & \text { Island }\end{array}$

Main objective of this sanctuary inauguration is to protect green sea turtle (Chelonia mydas) and hawksbill sea turtle (Erelmochelys imbricala) population which is known as the habitat and breeding sites in sandy beaches inside of conservation area's islands. Besides, it's global objective is to create main zone (sanctuary) for marine animal varieties along with its habitat such as turtle, dugong, siput mutiara and other species which can be utilized for commercial interest, thus nature reserve area can be utilized as a "reservoir" area.

Since the inauguration of this area as nature reserve, turtle hunting and egg catching still occurs by today (Sahertian and Noija, 1994; Far-Far, 2004) as well as the other natural resources exploitations in this area. This is in contradiction to the Act No. 5 of 1990. One of the exploitation causal factors in this area is that this location becomes customary land for generations for years and becomes the main income sources for them. Despite a local people, turtle hunting is also committed by fishermen from the outside of Maluku. It is estimated at about 4000 tails of maturity turtles are caught every year in Enu Island beach and commonly they are sold in Bali Island, Surabaya and Ujung Pandang. 


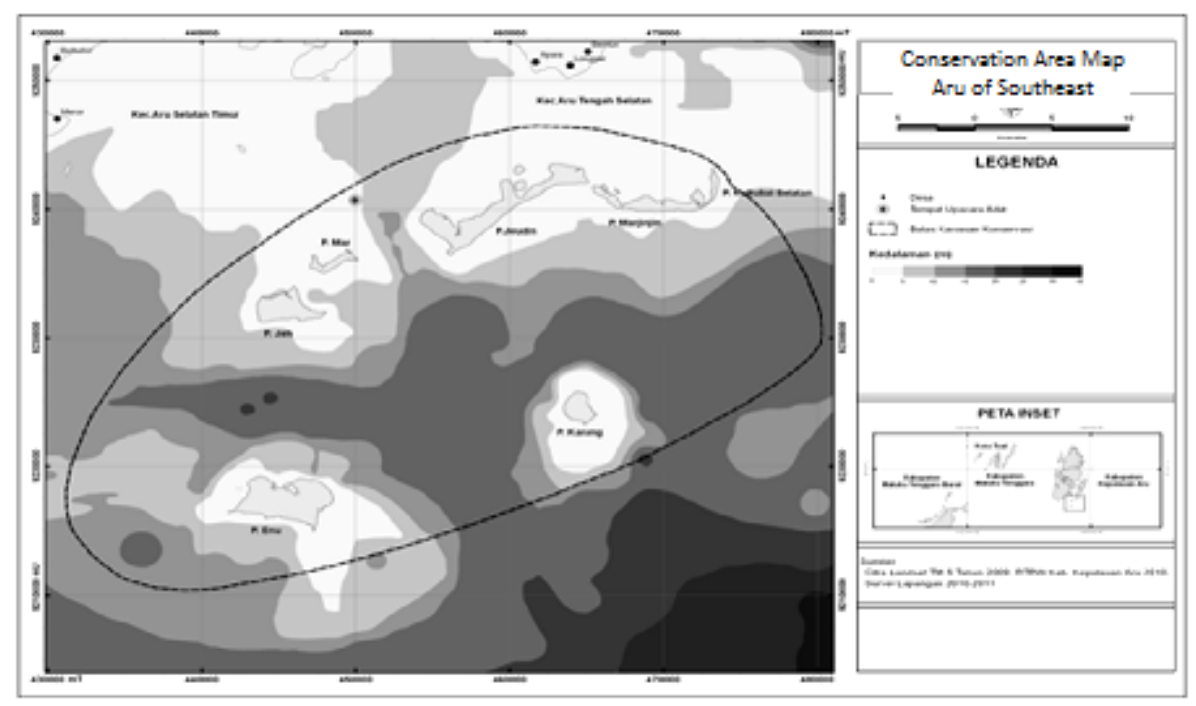

Figure 1 Map of Southeast Aru Conservation Area

90\% of people in Aru Islands work as fisherman and mostly they populate coastal area and small islands. Coastal area as a region which is illustrated by (Bengen, 2005) as a small shaft where all creatures interact inside of it, is a problem complexity with a very difficult matters to be managed. Small island is a lowland characterized by having small population, less of resources, remoteness, susceptible of natural disaster, high dependent level on resources, access and infrastructure limits and also having expensive public services.

As a region consisting of small islands, it has a unique fishery resource characteristics and endemic species such as turtle, dugong and dolphin as well as complex and vary resource ecosystem. Characteristic of fishery resource in this area indicates that;

First; fishery resources of the area have decreased either for its island ecosystem, mangrove ecosystem, seagrass ecosystem, coral reefs ecosystem or its open waters ecosystem. Second; cause of fishery resources decrease in this area is a consequence of inhabitant raising number, thus it raises the number of utilization activities legally or illegally. Third; the occurrence of various utilization activities in the area is an accumulation of utilization area limitation which is intended to be used as Marine Sanctuary areas.

Main role of protected area is being species diversity conservation, biodiversity conservation, along with ongoing resources management which can and should bring utilization for surrounding society (Brodziak et al., 2005; Worm at al., 2009). The Convention on Biological Diversity (The Secretariat of the Convention on Biological Diversity, 2008) states that protected area is an important tool for ecosystem and biological conservation as the supplier of resources and environment's service, thus it will form continuous development strategy basis. However, this effort often experiences obstacle in achieving the intended objective because the society is more isolated. It occurs because in the same time, people are trying to survive, especially in developing nations (Straede and Treue, 2006).

High utilization activities in this area are predicted as simultaneity of social, economic and cultural variables occurring in society's region, thus an analysis is needed to reveal 
social-economic and cultural factors leading to fishery resource decrease in this area. This study aims to determine some factors affecting society's decision in adhering or violating formal regulation about conservation and to formulate and to recommend alternative policy in order to execute participative and continuous utilization areas.

\section{Methodology of the Research}

Data sampling method on society's perception in conservation areas is conducted on structural interview approach supported by question lists. Collective data related to biological resource utilization patterns of coastal area and beaches is collected by using approach of Participatory Rural Appraisal (PRA) methods.

Data analysis is conducted using adherence analysis based on adherence basis model I, adherence basis model II and expanded adherence model.

\section{Adherence basis model I}

Adherence analysis using Adherence Basis Model I as follows:

\section{Information:}

$$
\mathrm{V}=\mathbf{f}\left(\mathbf{k}, \mathbf{G v}, \mathbf{G c}, \mathbf{P}_{1}\right)
$$

$$
\begin{aligned}
& \mathrm{V}=\text { Violation against formal regulation } \\
& \text { Variable } \mathrm{V} \text { is binary variables having } 2 \text { values, they are: } \\
& \text { 1. } \mathrm{V} \text { value }=1 \text {; if the violation rate is above the average } \\
& \text { 2. } V \text { value }=0 \text {; if the violation rate is under the average } \\
& \mathrm{k}=\text { Constant } \\
& \mathrm{Gv}=\text { Economic profit if regulation is violated which is measured by the average } \\
& \text { value of haul per trip if the fishes is caught surrounding Enu Island } \\
& \mathrm{Gc}=\text { Economic profit if regulation is adhered, which is measured by the average } \\
& \text { value of haul per trip if the fishes is caught outside of Enu Island } \\
& \text { conservation areas } \\
& \mathrm{P} 1=\text { Admonished, arrested and prosecuted by Jagawana (Rangers) if regulation } \\
& \text { is violated } \\
& \text { Information: } \\
& \mathrm{P} 1=1 \text {; if they had admonished by Jagawana } \\
& \mathrm{P} 1=0 \text {; If they had never admonished by Jagawana }
\end{aligned}
$$

\section{Adherence basis model II}

Description:

$$
\mathbf{V}=\mathbf{f}\left(\mathbf{k}, \mathbf{G v}, \mathbf{G c}, \mathbf{P}_{\mathbf{2}}\right)
$$

$\mathrm{P}_{2}=$ Determinant of various factors affecting the chances of being known, arrested and punished, then $\mathrm{P} 2$ is proxy by

$\mathrm{X}_{1}=$ Patrol frequency

$\mathrm{X}_{2}=$ Fisherman's marine motor capacity (HP or GT)

Hence, the formula is:

$\mathrm{V}=\mathrm{f}\left(\mathrm{k}, \mathrm{Gv}, \mathrm{Gc}, \mathrm{X}_{1}, \mathrm{X}_{2}\right)$ 


\section{Macrothink

\section{Extended Adherence Model}

\section{Information:}

$$
\mathrm{V}=\left(\mathbf{k}, \mathbf{G v}, \mathbf{G c}, \mathbf{Z}_{1}, \mathbf{Z}_{2}, \mathbf{Z}_{3}, \mathbf{Z}_{4}, \mathbf{Z}_{5}, \mathbf{Z}_{6}\right)
$$

$\mathrm{Z}_{1}=$ Education, quantified by the total years of attending formal education activities

$\mathrm{Z}_{2}=$ Size of Family, quantified by the number of family members.

$\mathrm{Z}_{3}=$ Age, quantified by the respondent age level

$\mathrm{Z}_{4}=$ Experience, measured by the number of respondent in attending education or training.

$\mathrm{Z}_{5}=$ Background, measured by the status of respondent as indigenous person or migrant.

- If $Z_{5}=1$; this man is a migrant

- If $Z_{5}=0$; this man is an indigenous person

$\mathrm{Z}_{6}=$ Religion, measured by the status of respondent for being a Christian or a Moslem.

- If $\mathrm{Z}_{6}=1$; this man is a Moslem

- If $\mathrm{Z}_{6}=0$; this man is a Christian

\section{Result and Discussion}

\subsection{The Analysis of Adherence Basis Model I}

Probit analysis result using adherence basis model I, considering violation as independent variable from which the independent variables are economic profit frequency if regulation is violated $(\mathrm{Gv})$, economic profit frequency if regulation is adhered $(\mathrm{Gc})$ and if they had admonished or had never admonished by Jagawana (P1), can be seen clearly in Table 1 .

This result shows that those three mentioned factors affect to the waywardness of society in conservation areas. Among those three variables, economic profit frequency if regulation is violated become the most dominant variable or have the greatest effect into waywardness, this is shown by $\mathrm{T}$ value by 3.988 . Usually, conservation activities have a tight relation with utilization level conducted by human being (Jackson and Sala, 2001; Stachowitsch, 2003; Halpern et al, 2008). Human resources having a great effect on coastal ecosystem, by which this case is in contradiction to human activities, gives various pressures which are simultaneously exploiting the coastal natural resources incorrectly (Crain et al., 2008; Darling and Côté, 2008; Doak et al., 2008; Halpern et al., 2008). 
Table 1. Probit Analysis Result on Adherence Basis Model I

\begin{tabular}{|c|c|c|}
\hline 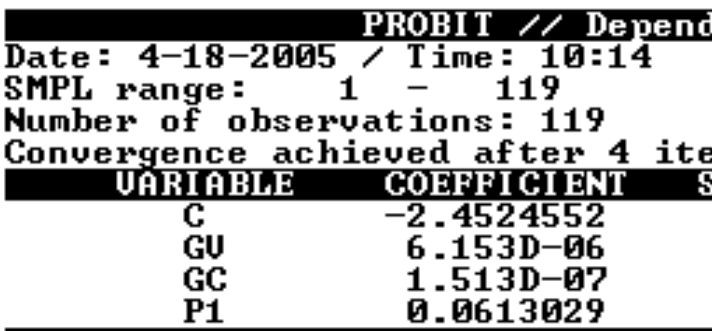 & 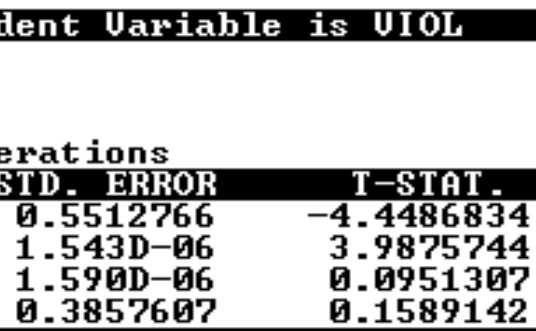 & $\begin{array}{c}\text { 2-TAIL SIG } \\
\text { G.141 } \\
0.156 \\
0.940 \\
0.900\end{array}$ \\
\hline 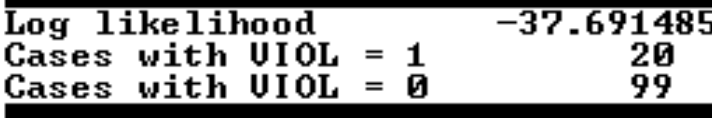 & & \\
\hline $\begin{array}{l}\text { MEAN ALI } \\
1.909690 \\
191974.79 \\
244327.73 \\
0.327731 \\
15.126050\end{array}$ & 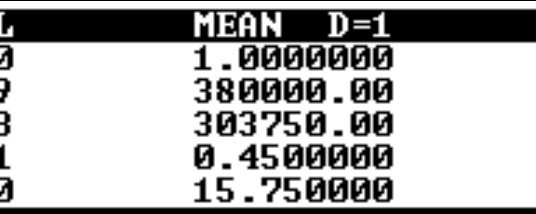 & 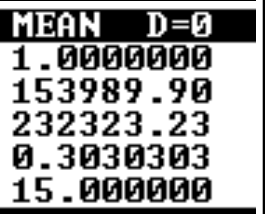 \\
\hline $\begin{array}{r}\text { Gouari } \\
0.303906 \\
-5.78 \mathrm{D}-07 \\
2.38 \mathrm{D}-12 \\
-7.66 \mathrm{D}-09 \\
7.78 \mathrm{D}-08\end{array}$ & $\begin{array}{l}\text { C.ance Matrix } \\
\text { C.GU } \\
\text { GU, GC } \\
\text { GC,GC } \\
\text { P1,P1 }\end{array}$ & $\begin{array}{r}-5.50 \mathrm{D}-07 \\
-0.059863 \\
-9.59 \mathrm{D}-14 \\
2.53 \mathrm{D}-12 \\
0.148811\end{array}$ \\
\hline
\end{tabular}

Magnitude of economic profit frequency effect if regulation is violated is triggered by dependence of society economically on the existing resources in conservation areas. Some factors affecting this dependence are that most of the petuanan territorial of local people are rented to entrepreneurs, thus conservation area become an alternative choice of resource utilization for economic interest in addition to existing resources kinds in this area. Number of this resource is reasonably available and it has high economic value such as siput mutiara, lola, sea cucumber, shark, abalone and turtle as well as another various biological resources. Conservation areas is an alternative choice considering that the history of this area is common property, thus it can be utilized by all people in Aru Islands.

Based on partially variable relationship as shown in covariance matrix, relationship between economic profit frequency if regulation is violated and the duty of Jagawana gives an indication that Jagawana has no supervision function in the area. To meet this challenge, it needs a carefully planned management which is truly and well performed and continues effort in monitoring and evaluating in order to better the existing management model.

\subsection{Analysis Result of Adherence Basis Model II}

Probit analysis result using adherence basis model II, considering violation (viol) as independent variable from which the independent variables are economic profit frequency if regulation is violated $(\mathrm{Gv})$, economic profit frequency if regulation is adhered $(\mathrm{Gc})$, patrol frequency $\left(\mathrm{X}_{1}\right)$ and fisherman's marine motor $\left(\mathrm{X}_{2}\right)$ is presented in Table 2. 


\section{MInstitute Macrothink $_{\text {Int }}$}

International Journal of Human Resource Studies

ISSN 2162-3058

2013, Vol. 3, No. 4

Based on Table 2, it is known that it is only economic profit factor if regulation is violated (Gv) affect to waywardness or violation. This is shown by $\mathrm{T}$ value by 4.225 . Magnitude of economic profit frequency effect if regulation is violated is triggered by dependence of society economically on the existing resources in conservation areas. This case is in line with some research stating that worldwide coastal ecosystem interact potentially with human activities, thus there are no coastal areas and small islands which are still pure or untouched by human being (Jackson and Sala, 2001; Stachowitsch, 2003;. Halpern et al, 2008). Human gives a huge effect on coastal areas (Vitousek et al, 1997; Halpern et al., 2008). Contradiction of human activities give a various pressures which are standing simultaneously in delivering pressing response to the ecosystem (Halpern at al, 2008).

Table 2. Probit Analysis Result on Adherence Basis Model II

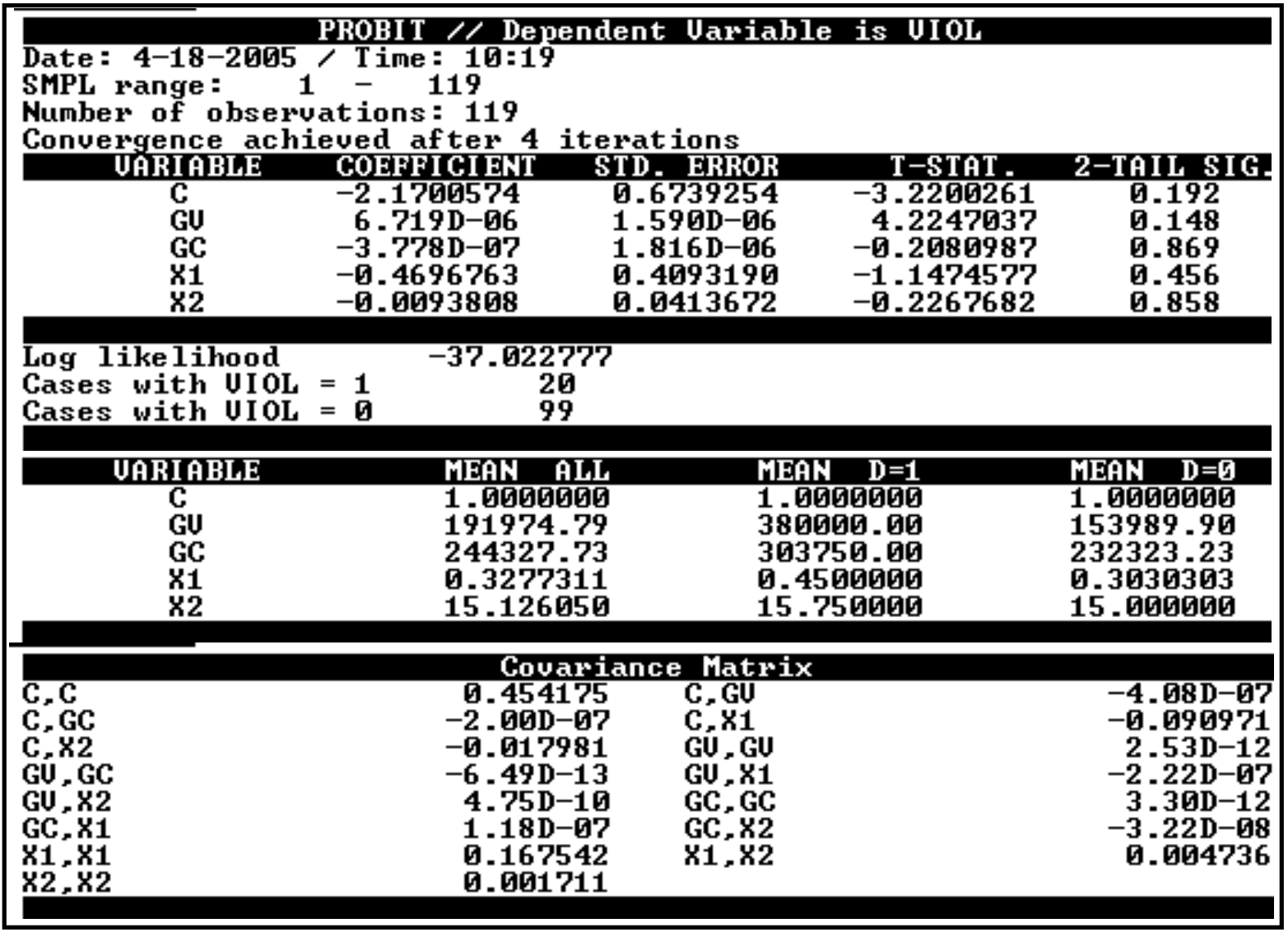

On the contrary, economic profit frequency if regulation is adhered (Gc), patrol frequency (X1) and fisherman's marine motor capacity (X2) do not affect to waywardness or violation. (Gc) variable do not give effect because resource utilization activities are conducted outside of conservation areas. It indicates that resource utilization activities outside of conservation areas contribute in limiting people's waywardness to utilize resources in conservation areas.

$\mathrm{X}_{1}$ variable with no effect indicates that there are problems in patrol process which should be performed by Jagawana (Rangers). These problems are caused by limited personnel number 


\section{MInstitute ${ }_{\text {Mink }}^{\text {Macrothink }}$}

International Journal of Human Resource Studies

ISSN 2162-3058

2013, Vol. 3, No. 4

in Jagawana (3 people only), patrol infrastructure constraints (1 speedboat only) and equivocal performance of law enforcement capacity by Jagawana. While fisherman's marine motor capacity $\left(\mathrm{X}_{2}\right)$ variable gives a very low chance for those who access this area. It can be seen from the marine motor capacity ranging from $10-25 \mathrm{HP}$. Low power of the existing marine motor capacity makes people feel afraid to utilize the existing resources inside the area, although the existence of marine motor capacity support their effort to reach conservation areas (positive relationship of $\mathrm{Gv}-\mathrm{X}_{2}$ variables).

\subsection{Analysis Result of Extended Adherence Model}

Probit analysis result using extended adherence basis model, considering violation as independent variable from which the independent variables are economic profit frequency if regulation is violated $(\mathrm{Gv})$, economic profit frequency if regulation is adhered $(\mathrm{Gc})$, education $\left(Z_{1}\right)$, and Size of Family $\left(Z_{2}\right)$, Age $\left(Z_{3}\right)$, Experience $\left(Z_{4}\right)$, Background $\left(Z_{5}\right)$ and religion $\left(Z_{6}\right)$ are clearly stated in Table 3.

Table 3. Probit Analysis Result against Extended Adherence Model

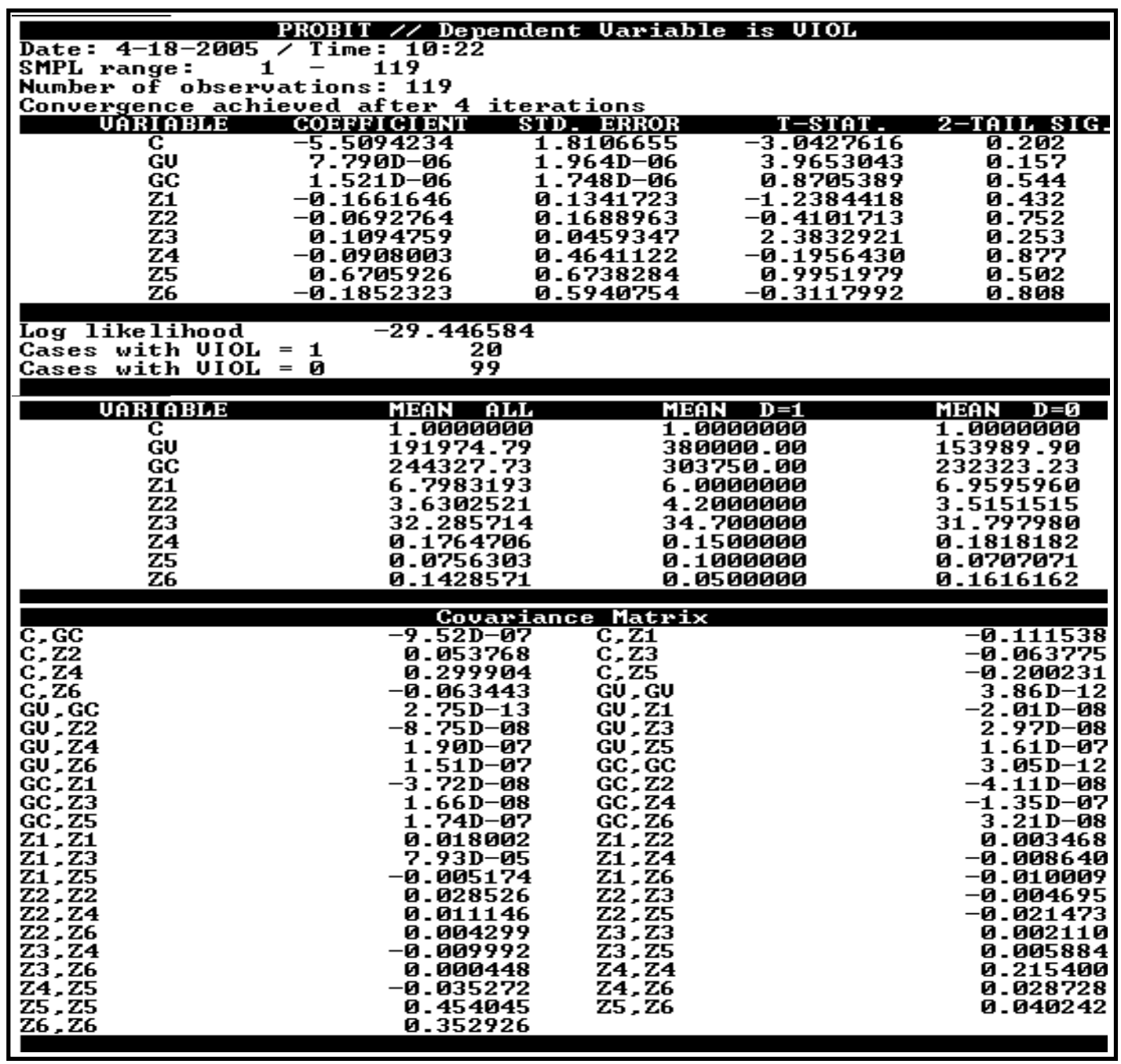

Based on Table 3, there are four factors affecting society's waywardness in conservation areas, they are: $\mathrm{Gv}, \mathrm{Gc}, \mathrm{Z}_{3}$ and $\mathrm{Z}_{5}$. Among those four variables, economic profit frequency if regulation is violated and age variable are variables with the highest effect on waywardness 
or violation. This is shown by $\mathrm{T}$ value of $\mathrm{Gv}$ by 3.965 and of $Z_{3}$ by 2.383 .

Gv variable as explained above is enough to give effect because of the existing dependence economically on the existing resources in conservation areas. While age variable tends to give effect because of two main factors, they are: (1) performance of the society who often access the areas are those who are still young and (2) those who are experienced and have knowledge on the existing biological resource potential surrounding the areas. This second factor is only found from several aged respondents ranging from 40 to 50 years old. These two factors encourage society surrounding conservation areas to have resources utilization business.

Partially variable relationship in covariance matrix shows that relationship between $G v-Z_{3}$, $\mathrm{Gv}-\mathrm{Z}_{4}, \mathrm{Gv}-\mathrm{Z}_{5}, \mathrm{Gc}-\mathrm{Z}_{3}$, and $\mathrm{Gc}-\mathrm{Z}_{5}$. is positive. Relationship between economic profit frequency if regulation is violated and age, experience, background and religion means that society's tendency to utilize biological resources in the areas is caused by productive age of society's capacity who are able to reach the areas compared with those who are non-productive. On the contrary, factor of experience also gives a chance for the society surrounding the areas to continuously utilize the existing resources because knowledge and technology mastery are grown well. Besides, migrant community tends to access these resources because they have low feeling of common property and usual low adherence level.

Another positive relationship between economic profit frequency outside of conservation areas and factor of age and background shows that society's effort capacity under productive age groups will tend to open chance for them to utilize the resources, whether those who stay inside or outside of conservation areas, even the booster factor of biological resource utilization become the reason of economic interest. While migrant community in their resource utilization pattern do not pay attention on the limitation of local community petuanan territorial (tradition), thus it opens a chance for them to continuously utilize the resources as long as their ability can do so.

\section{Conclusion}

Factors affecting society's decision in adhering or violating formal regulation about conservation include economic profit frequency if the society is fishing in conservation region, law enforcement capacity by Jagawana (EN: Rangers) against infringement in conservation area, productive age level and those who are experienced to access the sources as well as the background of the society, especially those who are migrant.

\section{References}

Bengen, D.G., 2005. Pentingnya Pengelolaan Wilayah Pesisir Terpadu Berbasis Ekosistem Bagi Keberlanjutan Pembangunan Kelautan. CRMP II. Gorontalo.

Crain, C.M., Kroeker, K., Halpern, B.S., 2008. Interactive and cumulative effects of multiple human stressors in marine systems. Journal Ecology 11:1304-1315.

Darling, E.S., and Côté, I.M., 2008. Quantifying the evidence for ecological synergism. Journal Ecology 11: 1278-1286.

DeFries, R., Hansen, A., Turner, B.L., Reid, R., and Liu, J., 2007. Land use change around 
protected areas: management to balance human needs and ecological function. Journal Ecology 17: 1031-1038.

Doak, D.F., Estes, J.A., Halpern B.S., Jacob. U/, Lindberg, D.R., Lovvorn, J., Monson, D.H., Tinker, M.T., Williams, T.M., Wootton, J.T., Carroll, I., Emmerson, M., Micheli. F., and Novak, M., 2008. Understanding and predicting ecological dynamics: are major surprises inevitable. Journal Ecology 89: 952-961.

Far-Far, R., 2005. Analisis Kebijakan tentang Pengelolaan Kawasan Konservasi Pulau Enu, Kepulauan Aru, Maluku. Thesis. Program Pascasarjana Universitas Pattimur, Program Studi Ilmu Kelautan. Ambon, 111 hal.

Gjertsen, H., 2005. Can habitat protection lead to improvements in human well-being? Evidence from marine protected areas in the Philippines. Journal World Development 33(2): 199-217.

Halpern, B.S., McLeod, K.L., Rosenberg, A,A., and Crowder, L.B., 2008. Managing for cumulative impacts in ecosystem-based management through ocean zoning. Journal Ocean and Coastal Management 51: 203-211.

IUCN World Commission on Protected Areas (IUCN-WCPA)., 2008. Establishing Resilient Marine Protected Area Networks-Making It Happen. Washington, DC: IUCN-WCPA, National Oceanic and Atmospheric Administration, and The Nature Conservation, $118 \mathrm{p}$.

Jackson, J.B.C., and Sala, E. 2001. Unnatural oceans. University of California, La Jolla, United States Journal Scientia Marina 65(2): 273-281.

Keputusan Menteri Kehutanan RI Nomor 27/Kpts-II/1991. Tentang Penetapan Kawasan Perairan Kepulauan Aru Bagian Tenggara sebagai Kawasan Cagar Alam laut Kepulauan Aru Bagian Tenggara. Jakarta,1991.

Keputusan Menteri Kelautan dan Perikanan Nomor 63 tahun 2009. Tentang Penetapan Kawasan Konservasi Perairan Nasional Kepulauan Aru Bagian Tenggara dan Laut di Sekitarnya di Provinsi Maluku.

Sahertian, I.H., and D.J., Noija., 1994. Studi Pendahuluan Ekologi dan Pengelolaan Penyu dan Kawasan Konservasi Aru Tenggara Kecamatan Pulau-pulau Aru Kabupaten Maluku Tenggara. Kerjasama Antara Direktorat Jenderal Konservasi Sumberdaya Alam, Program Konservasi Penyu (J.P. Schulz) dan EPM PUSDI-PSL UNPATTI, Ambon, 35 hal.

Stachowitsch, M., 2003. Research on intact marine ecosystems: a lost era. Marine Pollution Bulletin 46: 801-805.

Straede, S., and Treue, T., 2006. Beyond buffer zone protection: a comparative study of park and buffer zone products' importance to villagers living inside Royal Chitwan National Park and to villagers living in its buffer zone. Journal of Environmental Management 78: 251-267. Vitousek, P.M., Mooney, H.A., Lubchenco, J., and Melillo, J.M., 1997. Human domination of Earth's ecosystems. Journal Science 277: 494-499.

Worm, B., Hilborn, R., Baum, J.K., Branch, T.A., Collie, J.S., Costello, C., Fogarty, M.J., Fulton, E.A., Hutchings, J.A., Jennings, S., Jensen, O.P., Lotze, H.K., Mace, P.M., McClanahan, T.R., Minto, C., Palumbi, S.R., Parma, A.M., Ricard, D., Rosenberg, A.A.,Watson, R., and Zeller D. 2009. Rebuilding Global Fisheries. Journal Science 325 (5940): 578-585. 